\title{
A new crystalline form of $\beta$ - D-lactose prepared by oven drying a concentrated aqueous solution of D-lactose
}

Article

Published Version

Nicholls, D., Elleman, C., Shankland, N. and Shankland, K. (2019) A new crystalline form of $\beta$ - D-lactose prepared by oven drying a concentrated aqueous solution of D-lactose. Acta Crystallographica Section C - Crystal Structure Communications, 75 (7). pp. 904-909. ISSN 1600-5759 doi: https://doi.org/10.1107/S2053229619008210 Available at http://centaur.reading.ac.uk/83989/

It is advisable to refer to the publisher's version if you intend to cite from the work. See Guidance on citing.

To link to this article DOI: http://dx.doi.org/10.1107/S2053229619008210

Publisher: Wiley

All outputs in CentAUR are protected by Intellectual Property Rights law, including copyright law. Copyright and IPR is retained by the creators or other 
copyright holders. Terms and conditions for use of this material are defined in the End User Agreement.

\section{www.reading.ac.uk/centaur}

\section{CentAUR}

Central Archive at the University of Reading

Reading's research outputs online 


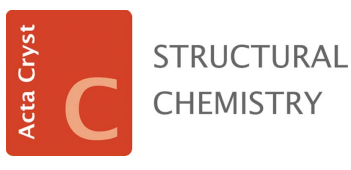

ISSN 2053-2296

Received 20 May 2019

Accepted 7 June 2019

Edited by A. R. Kennedy, University of Strathclyde, Scotland

Keywords: lactose; crystal structure; powder diffraction; DFT; disaccharide; polymorph.

CCDC reference: 1921562

Supporting information: this article has supporting information at journals.iucr.org/c

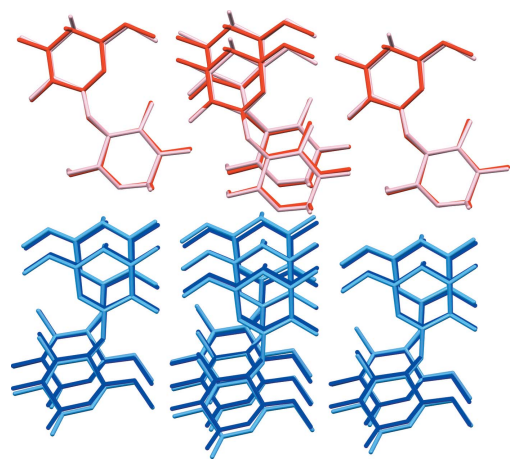

C 2019 International Union of Crystallography

\section{A new crystalline form of $\alpha \beta$-D-lactose prepared by oven drying a concentrated aqueous solution of D-lactose}

\author{
Daniel Nicholls, ${ }^{\mathrm{a}}$ Carole Elleman, ${ }^{\mathrm{b}}$ Norman Shankland ${ }^{\mathrm{c}}$ and Kenneth Shankland ${ }^{\mathrm{a} *}$
}

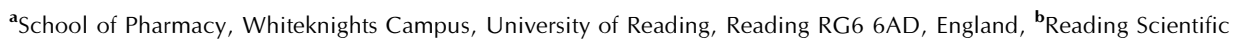
Services Limited, Mondelez, Whiteknights Campus, Reading RG6 6LA, England, and ${ }^{\mathbf{c}}$ CrystallografX Limited, 2 Stewart Street, Glasgow, Strathclyde G62 6BW, Scotland. *Correspondence e-mail: k.shankland@reading.ac.uk

A new crystalline form of $\alpha \beta$-D-lactose $\left(\mathrm{C}_{12} \mathrm{H}_{22} \mathrm{O}_{11}\right)$ has been prepared by the rapid drying of an approximately $40 \% w / v$ syrup of D-lactose. Initially identified from its novel powder X-ray diffraction pattern, the monoclinic crystal structure was solved from a microcrystal recovered from the generally polycrystalline mixed-phase residue obtained at the end of the drying step. This is the second crystalline form of $\alpha \beta$-D-lactose to be identified and it has a high degree of structural three-dimensional similarity to the previously identified triclinic form.

\section{Introduction}

D-Lactose (henceforth referred to simply as lactose) is a disaccharide that plays a very important role in the food and pharmaceutical industries (Booij, 1985; Audic et al., 2003; Gohel \& Jogani, 2005; Lifran et al., 2000), and whose solidstate properties in both the crystalline and the amorphous states have been studied extensively for decades (Hockett \& Hudson, 1931; Bushill et al., 1965; Kirk et al., 2007; Terban et al., 2016). It exists in two anomeric forms (Fig. 1) and several crystalline forms have been reported and fully characterized crystallographically (Table 1). Methods for the preparation of the various forms have been described in considerable detail in the publications cited in Table 1 and elsewhere (Simpson et al., 1982; Simone et al., 2019). Whilst other forms with varying mixes of the two anomers have been reported in the literature (e.g. an $\alpha: \beta$ ratio of 5:3; Hockett \& Hudson, 1931), these reports lack compelling crystallographic evidence to back them up. Indeed, the multidisciplinary nature of much of the research on lactose crystals and crystallization means that crystallography rarely plays the central role in the evaluation of experimental outcomes.

Our own interest in the solid-state properties of lactose stems from its significance in chocolate-crumb manufacture. Chocolate crumb is typically manufactured by the plate drying of a sweetened condensed milk (produced by either dissolving sucrose in milk or adding water to a sucrose and milk powder mixture) to $\sim 80-90 \%$ solids. Cocoa liquor is then mixed into this material, which is subsequently dried under vacuum to leave a chocolate-crumb product (Wells, 2009). The crumb method of chocolate manufacture is widely used by larger manufacturers, in the main due to the characteristic and brand-defining flavours that crumb chocolates possess. The vacuum drying stage provides the perfect conditions for Maillard reactions to occur, allowing for the development of complex cooked flavours that can vary significantly depending 
Table 1

Reported crystalline forms of D-lactose for which crystal structures are available.

\begin{tabular}{lllllllll}
\hline Form & Abbreviation & SpGrp & $Z$ & $Z^{\prime}$ & $T(\mathrm{~K})$ & Refcode & Type & Reference \\
\hline$\alpha$-Lactose monohydrate & $\alpha$-L.H $\mathrm{H}_{2} \mathrm{O}$ & $P 2_{1}$ & 2 & 1 & 150 & LACTOS11 & SX & Smith et al. (2005) \\
$\beta$-Lactose & $\beta$-L & $P 2_{1}$ & 2 & 1 & 293 & BLACTO & SX & Hirotsu \& Shimada (1974) \\
$\alpha$-Lactose (hygroscopic) & $\alpha$-LH & $P 2_{1}$ & 2 & 1 & 293 & EYOCUQ & PXRD & Platteau et al. (2004) \\
$\alpha$-Lactose (stable anhydrous) & $\alpha$-LS & $P 1$ & 2 & 2 & 293 & EYOCUQ01 & PXRD & Platteau et al. (2005) \\
$\alpha \beta$-lactose & $\alpha \beta$ - $\mathrm{L}_{\mathrm{T}}$ & $P 1$ & 2 & 2 & 120 & LAKKEO01 & SX & Guiry et al. $(2008)$ \\
\hline
\end{tabular}

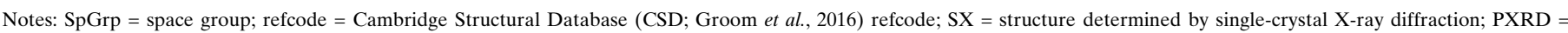
structure determined by powder X-ray diffraction.

on the exact conditions of the drying. This dependence of flavour upon conditions means that crumb-production methodologies are often maintained secret or patented (Wells, 2009).

We have previously accurately quantified the relative proportions of crystalline and amorphous sugars in both chocolate and chocolate crumb using quantitative phase analysis (QPA) based upon powder X-ray diffraction (PXRD) (Nicholls et al., 2018). Under the assumption that the majority of solid-state transformations of, and interactions between, the sugars in crumb manufacture occur during the initial plate drying of the sweetened condensed milk, we have explored the phase composition of the materials that result from drying of the somewhat simpler systems of concentrated sucrose and lactose syrups. Here, we report the results of drying syrups that contain only lactose.

\section{Experimental}

\subsection{Sample preparation}

$\alpha$-Lactose monohydrate (40 g; Sigma, BN: SLBQ8461V) was dissolved in purified water $(100 \mathrm{ml})$ at $45^{\circ} \mathrm{C}$ on a stirring hotplate. Stirring was continued for approximately $1 \mathrm{~h}$ after the visual disappearance of the last dispersed solid to ensure complete dissolution. Aliquots ( 3 or $6 \mathrm{ml}$ ) were then measured out and poured into $5.5 \mathrm{~cm}$ Petri dishes before being placed in a Lenton Thermal Designs fan oven at a number of different temperatures (Table 2). The temperature at the level of the tray inside the oven was confirmed using an RS52 Digital Thermometer equipped with a K-type thermocouple. Preliminary experiments showed that $30 \mathrm{~min}$ of drying was sufficient to completely dry a $3 \mathrm{ml}$ sample, but 90 min of drying was chosen for use throughout, in order to ensure complete drying of the $6 \mathrm{ml}$ samples. Upon removal from the fan oven, samples

Table 2

Sample drying conditions for the lactose syrups.

\begin{tabular}{lll}
\hline Sample number & Temperature $\left({ }^{\circ} \mathrm{C}\right)$ & Syrup volume $(\mathrm{ml})$ \\
\hline 1 & 100 & 3 \\
2 & 100 & 6 \\
3 & 110 & 3 \\
4 & 110 & 6 \\
5 & 120 & 3 \\
6 & 120 & 6 \\
7 & 140 & 3 \\
8 & 140 & 6 \\
\hline
\end{tabular}

were allowed to cool and the crystallized powders, which had hardened as off-white crusts in the Petri dishes, were removed using a spatula and stored in glass vials ready for analysis. Samples were lightly ground in an agate mortar and pestle in order to create free-flowing powders suitable for PXRD measurements.

\subsection{Powder X-ray diffraction}

Each powder was loaded into a $0.7 \mathrm{~mm}$ borosilicate glass capillary and mounted on a Bruker D8 Advance Diffractometer operating in transmission capillary geometry, with a LynxEye detector and monochromatic incident radiation of wavelength $1.54056 \AA$. Samples were typically scanned in the relatively narrow range $3-35^{\circ} 2 \theta$, with a $1 \mathrm{~h}$ data collection time, for phase identification purposes. All PXRD runs were performed within a few hours of the samples being removed from the oven. Data were analysed using the $E V A$ (Bruker, 2018), TOPAS (Coelho, 2018) and DASH (David et al., 2006) packages. PXRD data from samples of unground material, collected on a Bruker D8 operating in reflection flat plate mode, were used to verify that no phase transformations had been induced by the light grinding used in the sample preparation stage.
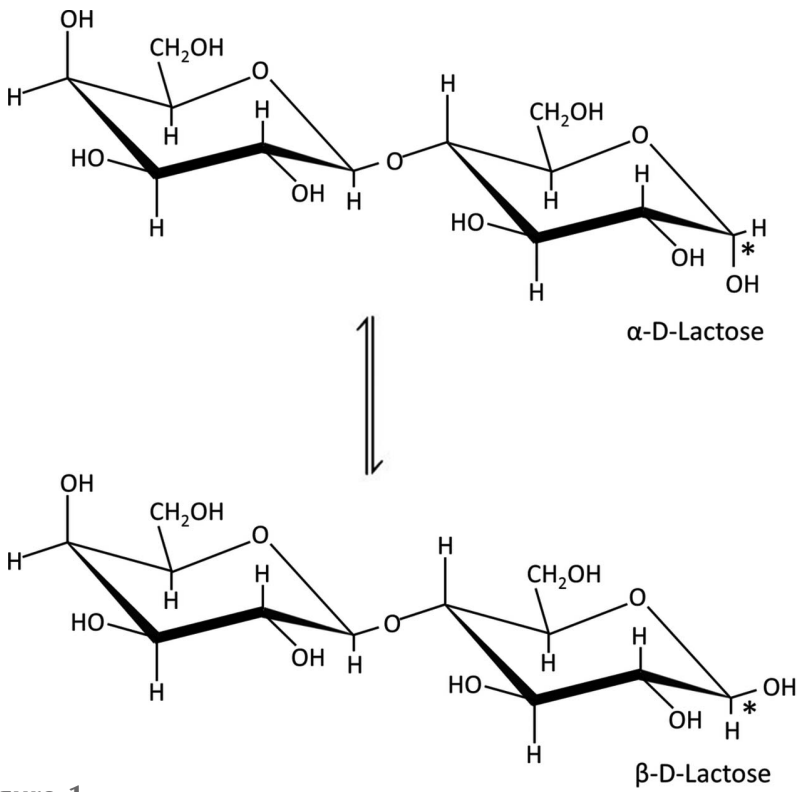

Figure 1

The molecular structures of the $\alpha$ and $\beta$ anomers of D-lactose, with the anomeric carbon identified by an asterisk. 
Table 3

Experimental details.

\begin{tabular}{|c|c|}
\hline \multicolumn{2}{|l|}{ Crystal data } \\
\hline Chemical formula & $\mathrm{C}_{12} \mathrm{H}_{22} \mathrm{O}_{11}$ \\
\hline$M_{\mathrm{r}}$ & 342.29 \\
\hline Crystal system, space group & Monoclinic, $P 2_{1}$ \\
\hline Temperature (K) & 100 \\
\hline$a, b, c(\AA)$ & $5.0044(3), 38.6364(14), 7.6007$ (4) \\
\hline$\beta\left({ }^{\circ}\right)$ & $106.200(5)$ \\
\hline$V\left(\AA^{3}\right)$ & $1411.26(13)$ \\
\hline$Z$ & 4 \\
\hline Radiation type & $\mathrm{Cu} K \alpha$ \\
\hline$\mu\left(\mathrm{mm}^{-1}\right)$ & 1.26 \\
\hline Crystal size (mm) & $0.08 \times 0.02 \times 0.02$ \\
\hline \multicolumn{2}{|l|}{ Data collection } \\
\hline Diffractometer & XtaLAB Synergy Dualflex HyPix \\
\hline Absorption correction & $\begin{array}{l}\text { Multi-scan (CrysAlis PRO; Rigaku } \\
\text { OD, 2019) }\end{array}$ \\
\hline$T_{\min }, T_{\max }$ & $0.804,1.000$ \\
\hline $\begin{array}{l}\text { No. of measured, independent and } \\
\text { observed }[I>2 \sigma(I)] \text { reflections }\end{array}$ & $8132,3861,3316$ \\
\hline$R_{\text {int }}$ & 0.057 \\
\hline$(\sin \theta / \lambda)_{\max }\left(\AA^{-1}\right)$ & 0.597 \\
\hline \multicolumn{2}{|l|}{ Refinement } \\
\hline$R\left[F^{2}>2 \sigma\left(F^{2}\right)\right], w R\left(F^{2}\right), S$ & $0.048,0.120,1.02$ \\
\hline No. of reflections & 3861 \\
\hline No. of parameters & 431 \\
\hline No. of restraints & 2 \\
\hline H-atom treatment & $\mathrm{H}$-atom parameters constrained \\
\hline$\Delta \rho_{\max }, \Delta \rho_{\min }\left(\mathrm{e} \AA^{-3}\right)$ & $0.38,-0.25$ \\
\hline
\end{tabular}

Computer programs: CrysAlis PRO (Rigaku OD, 2019), SHELXT (Sheldrick, 2015a), SHELXL2017 (Sheldrick, 2015b) and OLEX2 (Dolomanov et al., 2009).

\subsection{Single-crystal diffraction}

Dried samples were examined under a polarizing microscope to check for the possible occurrence of single crystals. Any potential single crystals were carefully removed and mounted on a Rigaku Synergy single-crystal diffractometer equipped with a microfocus copper X-ray source, a Hypix 3000 single-photon counting detector and an Oxford Cryosystems Cryostream cooling device. Atom H16 was restrained to a chemically sensible position.

\subsection{Periodic density functional theory calculations}

Periodic density functional theory with van der Waals dispersion corrections (DFT-D) was used for geometry optimization of the crystal structures of interest. The PBE functional was used with PAW (projector augmented wave) pseudopotentials and the Grimme D3 correction, as implemented in the pw.x executable of the QuantumEspresso program (Giannozzi et al., 2009, 2017). The lengths of bonds involving $\mathrm{H}$ atoms were normalized using Mercury CSD (Macrae et al., 2008) and input files for $p w . x$ were then created from these normalized CIFs using the cif2qe script of QuantumEspresso. Automatic $k$-point sampling was used; the kinetic energy cut-offs for wavefunctions and charge density were 50 and $400 \mathrm{Ry}$, respectively. The convergence thresholds for total energy and forces were set at 0.0001 and 0.001 a.u., respectively. Geometry optimization was carried out in two stages, as recommended by van de Streek \& Neumann (2010), with lattice parameters fixed at crystallographic values during an initial optimization and then allowed to vary in a subsequent optimization that started from the end-point of the fixed-cell calculation. All calculations were carried out on a Dell Precision T7810 workstation equipped with two $2.40 \mathrm{GHz}$ 8-core Intel Xeon E5-2630 v3 CPUs, running the Microsoft Windows 10 operating system, and using the Windows Subsystem for Linux (WSL) feature to allow the Linuxcompiled MPI-enabled $p w . x$ executable to utilize multiple cores.

\section{Results}

All of the dried samples exhibited PXRD patterns consistent with phase mixtures of crystalline lactose and, with the exception of those samples dried at $100{ }^{\circ} \mathrm{C}$, all possessed a strong contribution from a crystalline phase that did not correspond to any of the known phases listed in Table 1 (Fig. 2). Even after identifying one of the contributing phases as $\beta$-L, attempts to index the unknown contribution(s) using $D A S H$ and TOPAS were unsuccessful. Careful examination of the $120{ }^{\circ} \mathrm{C}$ sample under a polarizing microscope revealed that whilst the bulk of the sample was obviously polycrystalline, there were also a few very small single crystals present. Single-crystal diffraction showed that most of these were $\beta$-L, but one very small $(76 \times 24 \times 18 \mu \mathrm{m})$ single crystal indexed to a monoclinic cell that did not match any of the known forms. After careful Pawley refinement, to account for the $\sim 200{ }^{\circ} \mathrm{C}$ temperature difference between the single-crystal measurement and the PXRD experiments (see supporting information for details of the refinement approach used), it was found that this cell could explain the peak positions of the unknown phase in the PXRD pattern. A full single-crystal data collection resulted in the crystal structure of a new monoclinic form

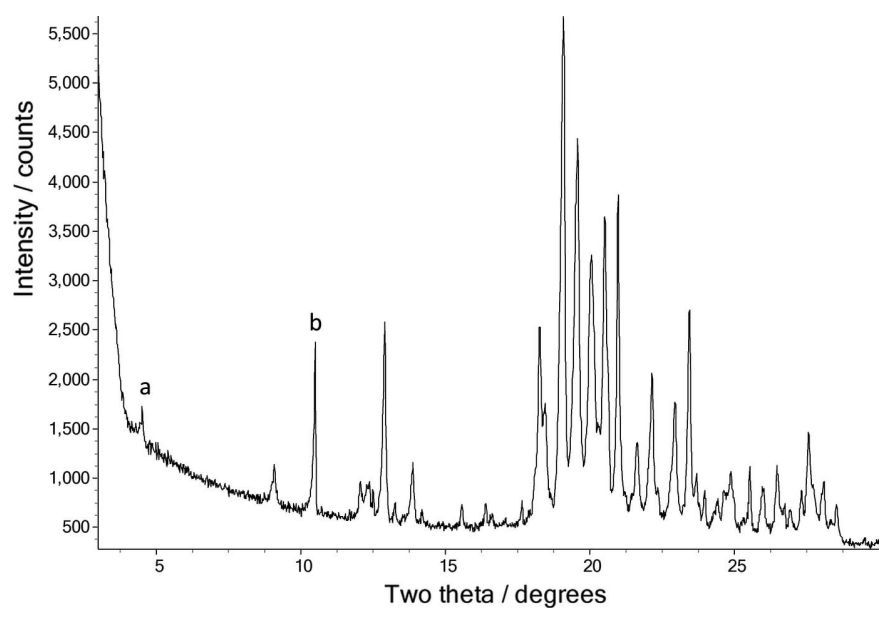

Figure 2

Powder X-ray diffraction data in the range $3-30^{\circ} 2 \theta$ collected from dried sample 3 . The data cannot be fully explained by the combination of any of the previously report crystal forms of lactose. The presence of $\beta$-L in the sample is evident from the diagnostic peak labelled $b$, whilst the lowangle peak labelled $a$ may be attributable to $\alpha$-LS, $\alpha \beta-\mathrm{L}_{\mathrm{T}}$ or the unknown form of lactose (subsequently identified as monoclinic $\alpha \beta-\mathrm{L}_{\mathrm{M}}$ ) that appears to comprise the bulk of the sample. 
Table 4

Relative abundance of crystalline lactose phases $(\% w / w)$ in each of the samples listed in Table 2, as obtained by Rietveld-based QPA.

The estimates are approximate, since the PXRD data had not been collected with the intention of performing QPA; more accurate and precise quantification would require longer data collections over a wider $2 \theta$ range.

\begin{tabular}{lccccc}
\hline Sample & $\alpha \beta-\mathrm{L}_{\mathrm{M}}$ & $\alpha \beta$ - $\mathrm{L}_{\mathrm{T}}$ & $\beta$-L & $\alpha$-LS & $\alpha$-L- $\mathrm{H}_{2} \mathrm{O}$ \\
\hline 1 & 0 & 0 & 41 & 0 & 59 \\
2 & 0 & 0 & 27 & 0 & 73 \\
3 & 57 & 8 & 23 & 12 & 0 \\
4 & 80 & 3 & 10 & 7 & 0 \\
5 & 81 & 19 & 0 & 0 & 0 \\
6 & 91 & 4 & 0 & 5 & 0 \\
7 & 90 & 10 & 0 & 0 & 0 \\
8 & 92 & 8 & 0 & 0 & 0 \\
\hline
\end{tabular}

of $\alpha \beta$-D-lactose (henceforth referred to as $\alpha \beta$ - $\mathrm{L}_{\mathrm{M}}$ ), whose crystallographic details are summarized in Table 3 .

Knowing the structure of $\alpha \beta-\mathrm{L}_{\mathrm{M}}$, it was then possible to perform Rietveld-based QPA on the PXRD patterns in order to quantify the amounts of the various forms of crystalline lactose present in the samples (Table 4 and Fig. 3).

\subsection{Discussion}

Despite the small size of the crystal retrieved from the phase mixture, the crystal structure determination of $\alpha \beta-\mathrm{L}_{\mathrm{M}}$ was relatively straightforward. Whilst the single-crystal diffraction data were of sufficient quality to allow the positioning of the majority of hydroxy $\mathrm{H}$ atoms directly from the difference Fourier maps, the location of a few such $\mathrm{H}$ atoms were less well determined. Geometry optimization in the solid state using DFT-D has been shown to be a powerful method for crystal structure verification (van de Streek \& Neumann, $2010,2014)$ and it was employed here to check the hydroxy-

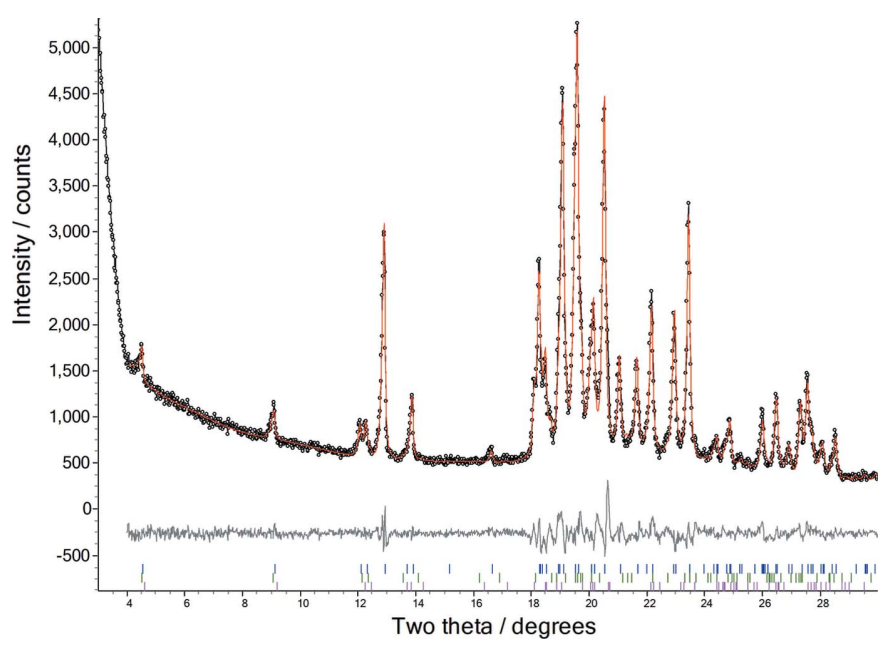

Figure 3

A three-phase Rietveld fit to the powder diffraction data in the range $3-30^{\circ} 2 \theta$ collected from dried sample 6 . Observed data are shown as black circles, the fit to the data is shown as a red line and the difference plot is shown in grey. Blue tick marks indicate reflection positions corresponding to $\alpha \beta$ - $\mathrm{L}_{\mathrm{M}}(91 \% w / w)$, green tick marks indicate reflection positions corresponding to $\alpha$-LS $(5 \% w / w)$ and pink tick marks indicate reflection positions corresponding to $\alpha \beta-\mathrm{L}_{\mathrm{T}}(4 \% w / w)$.

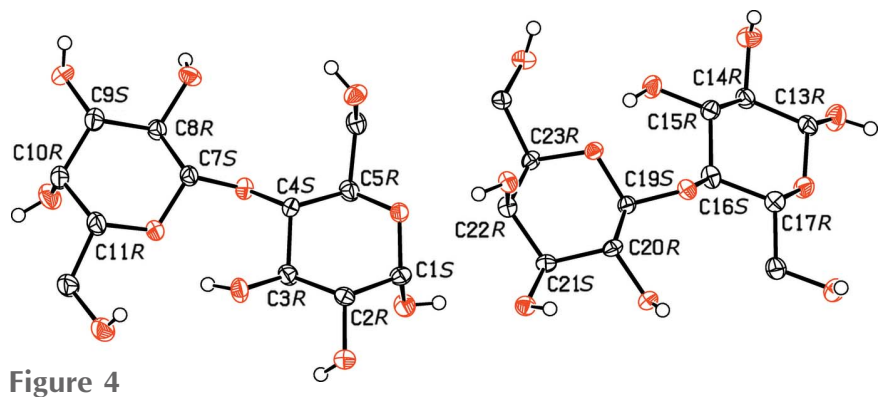

The contents of the asymmetric unit of the $\alpha \beta$ - $\mathrm{L}_{\mathrm{M}}$ crystal structure, with the stereochemistry of the chiral centres shown. The $\alpha$ anomer (left) has $\mathrm{C} 1 S$, whilst the $\beta$ anomer (right) has $\mathrm{C} 13 R$.

group orientations of the single-crystal structure. Fixed-cell geometry optimization of the refined crystal structure of $\alpha \beta$ - $\mathrm{L}_{\mathrm{M}}$ gave a structure in which the position of atom $\mathrm{H} 16$ in particular moved significantly; specifically, $0.92 \AA$, corresponding to a clockwise rotation of approximately $59^{\circ}$ around the $\mathrm{O} 9-\mathrm{C} 9$ bond to form a hydrogen bond $\left[\mathrm{O} 9-\mathrm{H} 16 \cdots \mathrm{O} 11^{\mathrm{i}}\right.$; symmetry code: (i) $x-1, y, z-1]$ that was not evident in the original single-crystal structure refinement. Whilst this optimization also improved the linearity of some other hydrogen bonds (e.g. those involving $\mathrm{H} 22, \mathrm{H} 36$ and $\mathrm{H} 38$ ), only the position change of H16 was deemed to be significant enough to merit revisiting the single-crystal structure refinement. A restraint was used to hold H16 in the correct (i.e. DFT-D) hydrogen-bonding position in the final refinement. The asymmetric unit of the crystal structure of $\alpha \beta-\mathrm{L}_{\mathrm{M}}$, with the stereochemistry of the chiral centres highlighted, is shown in Fig. 4.

Differences between the experimental and energy-minimized $\alpha \beta$ - $\mathrm{L}_{\mathrm{M}}$ crystal structures are relatively small; a 15molecule overlay in Mercury returned an r.m.s. deviation (RMSD) of $0.054 \AA$, a favourable value that supports the correctness of experimental $\alpha \beta-\mathrm{L}_{\mathrm{M}}$ (van de Streek \& Neumann, 2010). The $\alpha \beta-\mathrm{L}_{\mathrm{M}}$ and $\alpha \beta$ - $\mathrm{L}_{\mathrm{T}}$ polymorphs each comprise alternating two-dimensional layers of $\alpha$ and $\beta$ anomers (Fig. 5), and $\alpha \beta$ - $\mathrm{L}_{\mathrm{M}}$ shows a high degree of threedimensional similarity with $\alpha \beta$ - $\mathrm{L}_{\mathrm{T}}$ (Fig. 6 and supporting information). Unsurprisingly, the DFT-D total energy difference between the asymmetric units of the polymorphs is too small to infer the rank order of stability: $\Delta E_{\left(\alpha \beta-\mathrm{L}_{\mathrm{M}}-\alpha \beta-\mathrm{L}_{\mathrm{T}}\right)}=$ $1.8 \mathrm{~kJ} \mathrm{~mol}^{-1}$, with the energy for $\alpha \beta$ - $\mathrm{L}_{\mathrm{T}}$ calculated using the corrected and energy-minimized $\alpha \beta-\mathrm{L}_{\mathrm{T}}$ crystal structure of van de Streek \& Neumann (2014).

The use of PXRD was crucial in identifying the presence of a new crystalline form of lactose. However, the complexity of the phase mixtures returned in the crystallizations, coupled with the relatively large unit cell size of $\alpha \beta-\mathrm{L}_{\mathrm{M}}$, meant that we were unable to index it from the PXRD alone.

Appearing to comprise the bulk of the material recovered from crystallizations occurring at temperatures of $110{ }^{\circ} \mathrm{C}$ or above, the $\alpha \beta$ - $\mathrm{L}_{\mathrm{M}}$ phase was clearly polycrystalline in nature; from all the samples prepared, only one very small crystal of $\alpha \beta$ - $\mathrm{L}_{\mathrm{M}}$ suitable for single-crystal diffraction was ever recovered. In spite of its diminutive size, the crystal diffracted sufficiently well to yield a crystal structure that, as evidenced 


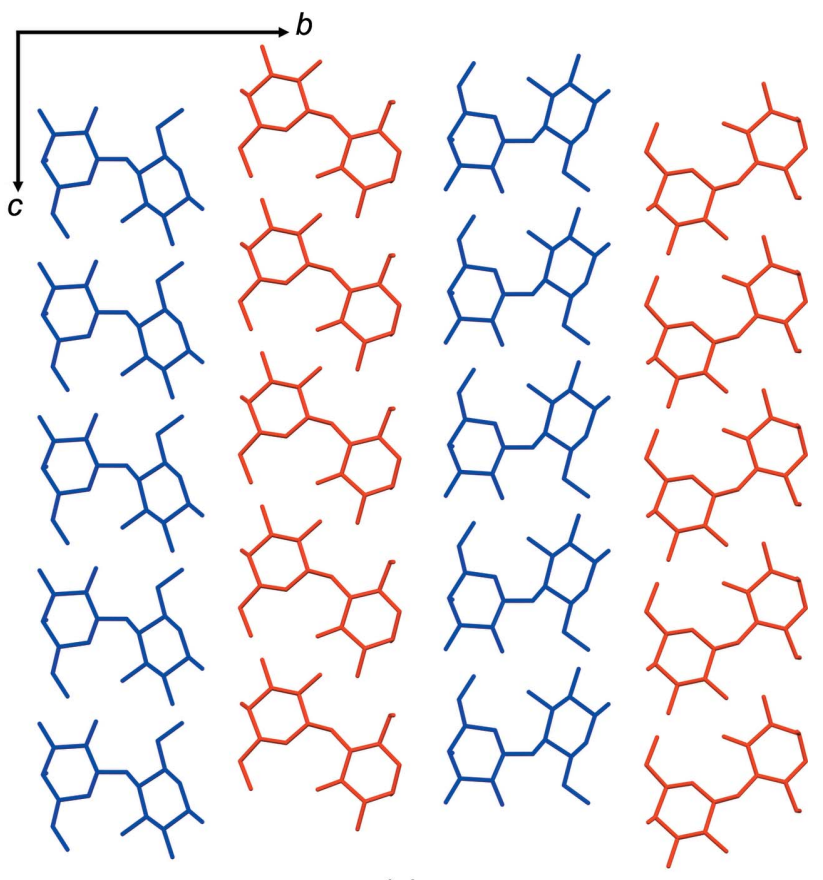

(a)

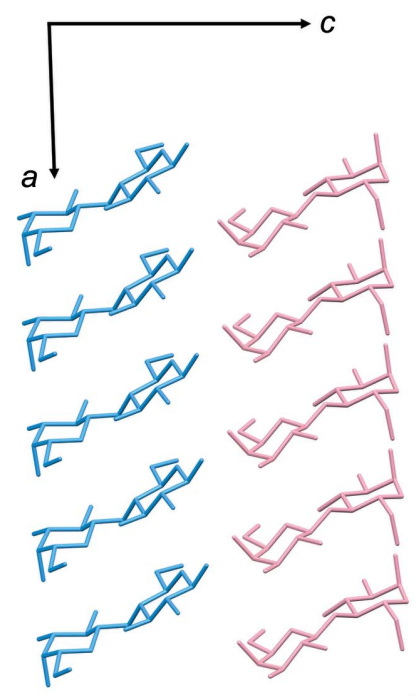

(b)

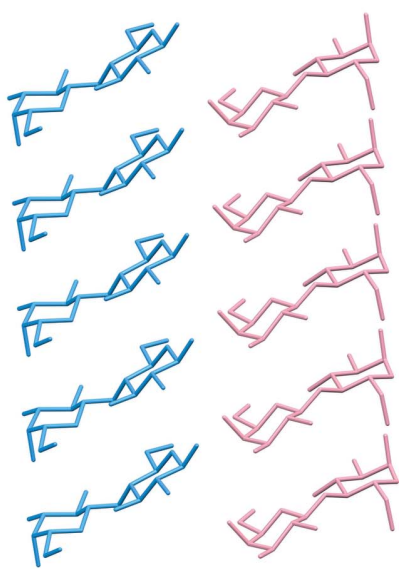

Figure 5

Packing diagrams of (a) $\alpha \beta$ - $\mathrm{L}_{\mathrm{M}}$ and (b) $\alpha \beta$ - $\mathrm{L}_{\mathrm{T}}$. Both crystal structures comprise alternating two-dimensional layers of the $\alpha$ (red, salmon) and $\beta$ anomers (blue, light blue).

by Rietveld-based QPA, proved to constitute the majority phase in bulk samples 3 to 8 . Whilst we did not attempt any quantification of the amorphous content, the relatively low backgrounds of all the collected PXRD data sets suggest that there is little in the way of amorphous material in the recrystallized samples and we observed no changes in the PXRD of samples as a function of time over a timescale of 12 months.

The QPA analysis shows that the composition of the phase mixtures returned from the syrup-drying experiments exhibit a temperature dependence. It also shows clearly that the previously identified form $\alpha \beta$ - $\mathrm{L}_{\mathrm{T}}$ crystallizes alongside $\alpha \beta$ - $\mathrm{L}_{\mathrm{M}}$

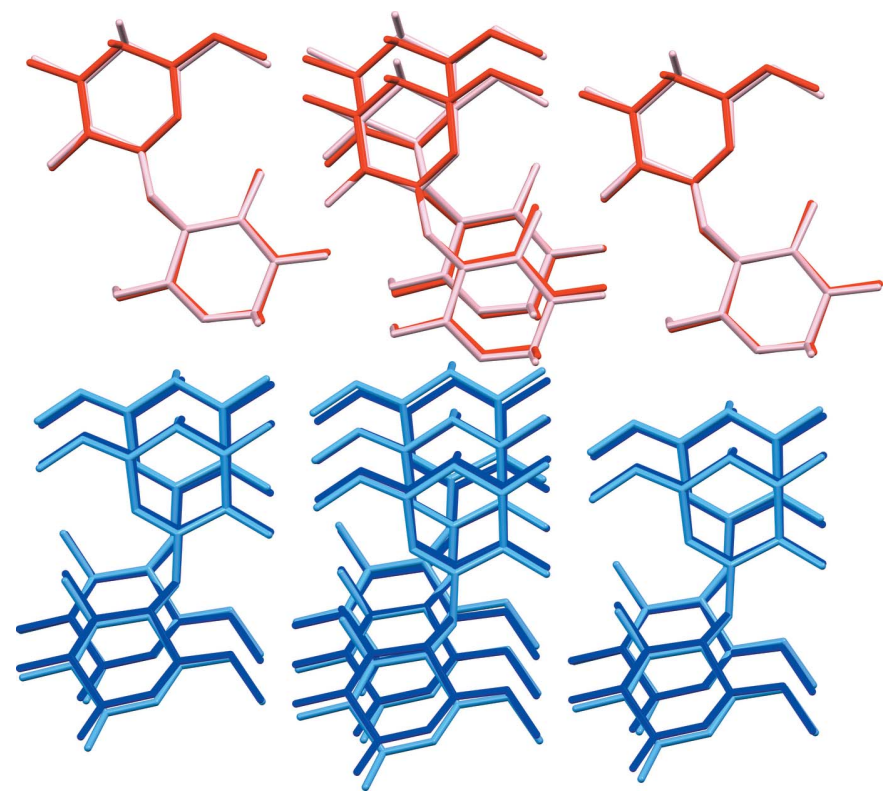

Figure 6

The three-dimensional similarity of $\alpha \beta$ - $\mathrm{L}_{\mathrm{M}}$ and $\alpha \beta$ - $\mathrm{L}_{\mathrm{T}}$, illustrated by overlaying molecules in each structure using the 'Crystal Packing Similarity' feature of Mercury (Macrae et al., 2008). The RMSD for the overlay is $0.336 \AA$ and the colour coding used is the same as in Fig. 5 .

in the syrup-drying process, adding to the existing methods of Lefebvre et al. (2005) and Guiry et al. (2008) for the crystallization of $\alpha \beta$ - $\mathrm{L}_{\mathrm{T}}$.

\section{Conclusion}

The use of PXRD, single-crystal diffraction and periodic DFT-D has allowed the identification and structure determination of a new monoclinic crystalline form of $\alpha \beta$-D-lactose. The structure adds to the five known well-characterized forms of D-lactose. Many recent publications (Fan \& Roos, 2015; Haque \& Roos, 2005; Jouppila et al., 1998; Nijdam et al., 2007; Saffari et al., 2015; Yazdanpanah \& Langrish, 2011) continue to cite literature whose lactose phase identification methods are sub-optimal (i.e. based upon tabulated PXRD line positions and estimated intensities), and which continue to refer to mixed phase forms (such as $\alpha: \beta=5: 3$ and $\alpha: \beta=4: 1$ ) that lack compelling crystallographic evidence for their existence. It is recommended that where PXRD is to play a role in phase identification in lactose mixtures, the analysis should be based on whole-pattern fitting methods using verified crystal structures, and ideally employ transmission (as opposed to the more widely used reflection) instrument geometry, in order to minimize the confounding effects of preferred orientation in samples.

\section{Acknowledgements}

The authors acknowledge the University of Reading's Chemical Analysis Facility for X-ray diffraction facilities and thank Mr Nick Spencer for his technical support of those facilities 


\section{Funding information}

Funding for this research was provided by: Biotechnology and Biological Sciences Research Council (BBSRC) and Mondelez Ltd (Case Award BB/L015730/1, to DN).

\section{References}

Audic, J.-L., Chaufer, B. \& Daufin, G. (2003). Lait, 83, 417-438.

Booij, C. J. (1985). Int. J. Dairy Technol. 38, 105-109.

Bruker (2018). EVA. Bruker AXS Inc., Madison, Wisconsin, USA. https://www.bruker.com/products/x-ray-diffraction-and-elementalanalysis/x-ray-diffraction/xrd-software/eva/overview.html.

Bushill, J. H., Wright, W. B., Fuller, C. H. F. \& Bell, A. V. (1965). J. Sci. Food Agric. 16, 622-628.

Coelho, A. A. (2018). J. Appl. Cryst. 51, 210-218.

David, W. I. F., Shankland, K., van de Streek, J., Pidcock, E., Motherwell, W. D. S. \& Cole, J. C. (2006). J. Appl. Cryst. 39, 910915.

Dolomanov, O. V., Bourhis, L. J., Gildea, R. J., Howard, J. A. K. \& Puschmann, H. (2009). J. Appl. Cryst. 42, 339-341.

Fan, F. H. \& Roos, Y. H. (2015). Food. Res. Int. 67, 1-11.

Giannozzi, P., et al. (2017). J. Phys. Condens. Matter, 29, article No. 465901.

Giannozzi, P., et al. (2009). J. Phys. Condens. Matter, 21, article No. 395502.

Gohel, M. C. J. P. D. \& Jogani, P. D. (2005). J. Pharm. Pharm. Sci. 8, 76-93.

Groom, C. R., Bruno, I. J., Lightfoot, M. P. \& Ward, S. C. (2016). Acta Cryst. B72, 171-179.

Guiry, K. P., Coles, S. J., Moynihan, H. A. \& Lawrence, S. E. (2008). Cryst. Growth Des. 8, 3927-3934.

Haque, K. \& Roos, Y. H. (2005). Carbohydr. Res. 340, 293-301.

Hirotsu, K. \& Shimada, A. (1974). Bull. Chem. Soc. Jpn, 47, 18721879.

Hockett, R. C. \& Hudson, C. S. (1931). J. Am. Chem. Soc. 53, 44554456.

Jouppila, K., Kansikas, J. \& Roos, Y. H. (1998). Biotechnol. Prog. 14, 347-350.
Kirk, J. H., Dann, S. E. \& Blatchford, C. G. (2007). Int. J. Pharm. 334, 103-114.

Lefebvre, J., Willart, J.-F., Caron, V., Lefort, R., Affouard, F. \& Danède, F. (2005). Acta Cryst. B61, 455-463.

Lifran, E. V., Hourigan, J. A., Sleigh, R. W. \& Johnson, R. L. (2000). Food Aust. 52, 120-136.

Macrae, C. F., Bruno, I. J., Chisholm, J. A., Edgington, P. R., McCabe, P., Pidcock, E., Rodriguez-Monge, L., Taylor, R., van de Streek, J. \& Wood, P. A. (2008). J. Appl. Cryst. 41, 466-470.

Nicholls, D., Shankland, K., Spillman, M. \& Elleman, C. (2018). Food Anal. Methods, 11, 2673-2681.

Nijdam, J., Ibach, A., Eichhorn, K. \& Kind, M. (2007). Carbohydr. Res. 342, 2354-2364.

Platteau, C., Lefebvre, J., Affouard, F. \& Derollez, P. (2004). Acta Cryst. B60, 453-460.

Platteau, C., Lefebvre, J., Affouard, F., Willart, J.-F., Derollez, P. \& Mallet, F. (2005). Acta Cryst. B61, 185-191.

Rigaku OD (2019). CrysAlis PRO. Rigaku Oxford Diffraction Ltd, Yarnton, Oxfordshire, England.

Saffari, M., Ebrahimi, A. \& Langrish, T. (2015). J. Food Eng. 164, $1-9$.

Sheldrick, G. M. (2015a). Acta Cryst. A71, 3-8.

Sheldrick, G. M. (2015b). Acta Cryst. C71, 3-8.

Simone, E., Tyler, A. I. I., Kuah, D., Bao, X. F., Ries, M. E. \& Baker, D. (2019). Org. Process Res. Dev. 23, 220-233.

Simpson, T. D., Parrish, F. W. \& Nelson, M. L. (1982). J. Food Sci. 47, 1948-1951.

Smith, J. H., Dann, S. E., Elsegood, M. R. J., Dale, S. H. \& Blatchford, C. G. (2005). Acta Cryst. E61, o2499-o2501.

Streek, J. van de \& Neumann, M. A. (2010). Acta Cryst. B66, 544558.

Streek, J. van de \& Neumann, M. A. (2014). Acta Cryst. B70, 1020 1032.

Terban, M. W., Cheung, E. Y., Krolikowski, P. \& Billinge, S. J. L. (2016). Cryst. Growth Des. 16, 210-220.

Wells, M. A. (2009). In Beckett's Industrial Chocolate Manufacture and Use, edited by S. Beckett. UK: Wiley-Blackwell.

Yazdanpanah, N. \& Langrish, T. A. G. (2011). Drying Technol. 29, 1046-1057. 


\section{supporting information}

Acta Cryst. (2019). C75, 904-909 [https://doi.org/10.1107/S2053229619008210]

\section{A new crystalline form of $\alpha \beta$-D-lactose prepared by oven drying a concentrated aqueous solution of D-lactose}

\section{Daniel Nicholls, Carole Elleman, Norman Shankland and Kenneth Shankland}

Computing details

Data collection: CrysAlis PRO (Rigaku OD, 2019); cell refinement: CrysAlis PRO (Rigaku OD, 2019); data reduction: CrysAlis PRO (Rigaku OD, 2019); program(s) used to solve structure: SHELXT (Sheldrick, 2015a); program(s) used to refine structure: SHELXL2017 (Sheldrick, 2015b); molecular graphics: OLEX2 (Dolomanov et al., 2009); software used to prepare material for publication: OLEX2 (Dolomanov et al., 2009).

$\alpha \beta$ - $D$-Lactose

Crystal data

$\mathrm{C}_{12} \mathrm{H}_{22} \mathrm{O}_{11}$

$M_{r}=342.29$

Monoclinic, $P 2_{1}$

$a=5.0044(3) \AA$

$b=38.6364(14) \AA$

$c=7.6007(4) \AA$

$\beta=106.200(5)^{\circ}$

$V=1411.26(13) \AA^{3}$

$Z=4$

\section{Data collection}

XtaLAB Synergy Dualflex HyPix diffractometer

Radiation source: micro-focus sealed X-ray tube, PhotonJet $(\mathrm{Cu}) \mathrm{X}$-ray Source

Mirror monochromator

Detector resolution: 10.0000 pixels $\mathrm{mm}^{-1}$

$\omega$ scans

Absorption correction: multi-scan

(CrysAlis PRO; Rigaku OD, 2019)

\section{Refinement}

Refinement on $F^{2}$

Least-squares matrix: full

$R\left[F^{2}>2 \sigma\left(F^{2}\right)\right]=0.048$

$w R\left(F^{2}\right)=0.120$

$S=1.01$

3861 reflections

431 parameters

2 restraints

Primary atom site location: dual
$F(000)=728$

$D_{\mathrm{x}}=1.611 \mathrm{Mg} \mathrm{m}^{-3}$

$\mathrm{Cu} K \alpha$ radiation, $\lambda=1.54184 \AA$

Cell parameters from 3068 reflections

$\theta=4.5-72.2^{\circ}$

$\mu=1.26 \mathrm{~mm}^{-1}$

$T=100 \mathrm{~K}$

Clear block, colourless

$0.08 \times 0.02 \times 0.02 \mathrm{~mm}$

$T_{\min }=0.804, T_{\max }=1.000$

8132 measured reflections

3861 independent reflections

3316 reflections with $I>2 \sigma(I)$

$R_{\text {int }}=0.057$

$\theta_{\max }=67.1^{\circ}, \theta_{\min }=4.6^{\circ}$

$h=-5 \rightarrow 5$

$k=-46 \rightarrow 41$

$l=-8 \rightarrow 9$

Hydrogen site location: inferred from neighbouring sites

$\mathrm{H}$-atom parameters constrained

$w=1 /\left[\sigma^{2}\left(F_{\mathrm{o}}^{2}\right)+(0.0705 P)^{2}\right]$

where $P=\left(F_{\mathrm{o}}^{2}+2 F_{\mathrm{c}}^{2}\right) / 3$

$(\Delta / \sigma)_{\max }<0.001$

$\Delta \rho_{\max }=0.38 \mathrm{e} \AA^{-3}$

$\Delta \rho_{\min }=-0.25 \mathrm{e} \AA^{-3}$ 
Absolute structure: Flack $x$ determined using 989 quotients $[(\mathrm{I}+)-(\mathrm{I}-)] /[(\mathrm{I}+)+(\mathrm{I}-)]$ (Parsons et al., 2013)

Absolute structure parameter: -0.3 (2)

Special details

Geometry. All esds (except the esd in the dihedral angle between two 1.s. planes) are estimated using the full covariance matrix. The cell esds are taken into account individually in the estimation of esds in distances, angles and torsion angles; correlations between esds in cell parameters are only used when they are defined by crystal symmetry. An approximate (isotropic) treatment of cell esds is used for estimating esds involving l.s. planes.

Fractional atomic coordinates and isotropic or equivalent isotropic displacement parameters $\left(\AA^{2}\right)$

\begin{tabular}{|c|c|c|c|c|}
\hline & $x$ & $y$ & $z$ & $U_{\text {iso }} * / U_{\text {eq }}$ \\
\hline $\mathrm{O} 15$ & 1.0019 (7) & $0.63348(8)$ & $0.4404(5)$ & $0.0179(7)$ \\
\hline $\mathrm{O} 5$ & $0.2846(7)$ & $0.46940(8)$ & $0.5118(5)$ & $0.0194(7)$ \\
\hline $\mathrm{O} 18$ & $0.7775(7)$ & $0.58691(8)$ & $0.2858(5)$ & $0.0169(7)$ \\
\hline O19 & $1.1446(7)$ & $0.59577(9)$ & $0.7705(5)$ & $0.0205(8)$ \\
\hline H36 & 1.070821 & 0.602565 & 0.847849 & $0.031 *$ \\
\hline $\mathrm{O} 4$ & $0.2455(7)$ & $0.38585(9)$ & $0.2851(5)$ & $0.0200(7)$ \\
\hline $\mathrm{O} 21$ & $0.4712(7)$ & $0.53444(8)$ & $0.4336(5)$ & $0.0184(7)$ \\
\hline $\mathrm{H} 40$ & 0.418775 & 0.516359 & 0.469732 & $0.028 *$ \\
\hline $\mathrm{O} 2$ & $0.5130(8)$ & $0.41768(9)$ & $0.9313(5)$ & $0.0223(8)$ \\
\hline $\mathrm{H} 4$ & 0.620665 & 0.402031 & 0.924954 & $0.034 *$ \\
\hline $\mathrm{O} 22$ & $0.6082(7)$ & $0.56071(10)$ & $-0.0652(5)$ & $0.0231(8)$ \\
\hline $\mathrm{H} 44$ & 0.466259 & 0.570697 & -0.123045 & $0.035^{*}$ \\
\hline $\mathrm{O} 8$ & $-0.0739(8)$ & $0.37157(9)$ & $-0.0756(5)$ & $0.0232(8)$ \\
\hline H14 & -0.012004 & 0.371203 & -0.164754 & $0.035^{*}$ \\
\hline O6 & $-0.1588(7)$ & $0.46187(10)$ & $0.1878(5)$ & $0.0249(8)$ \\
\hline H11 & -0.258564 & 0.452202 & 0.097042 & $0.037 *$ \\
\hline $\mathrm{O} 1$ & $0.7333(7)$ & $0.45878(9)$ & $0.7036(5)$ & $0.0246(8)$ \\
\hline $\mathrm{H} 2$ & 0.797135 & 0.478314 & 0.703099 & $0.037 *$ \\
\hline $\mathrm{O} 17$ & $1.5575(8)$ & $0.70155(9)$ & $0.7603(5)$ & $0.0248(8)$ \\
\hline H33 & 1.429173 & 0.705620 & 0.804827 & $0.037 *$ \\
\hline O16 & $1.4840(8)$ & $0.69894(9)$ & $0.3686(5)$ & $0.0238(8)$ \\
\hline $\mathrm{O} 20$ & $0.9133(7)$ & $0.52636(9)$ & $0.7562(5)$ & $0.0208(7)$ \\
\hline H38 & 0.846224 & 0.539715 & 0.816208 & $0.031 *$ \\
\hline $\mathrm{O} 13$ & $1.1060(8)$ & $0.68991(10)$ & $-0.1138(5)$ & $0.0258(8)$ \\
\hline $\mathrm{H} 26$ & 0.944059 & 0.695554 & -0.125458 & $0.039 *$ \\
\hline $\mathrm{O} 12$ & $1.5346(9)$ & $0.72657(10)$ & $0.1161(6)$ & $0.0299(9)$ \\
\hline $\mathrm{H} 24$ & 1.586499 & 0.744594 & 0.172184 & $0.045^{*}$ \\
\hline $\mathrm{O} 3$ & $0.2259(8)$ & $0.36874(9)$ & $0.6726(5)$ & $0.0257(8)$ \\
\hline H6 & 0.244093 & 0.351721 & 0.612530 & $0.039 *$ \\
\hline O11 & $0.2818(9)$ & $0.28643(10)$ & $0.6678(5)$ & $0.0315(9)$ \\
\hline $\mathrm{H} 22$ & 0.150035 & 0.298206 & 0.677066 & $0.047^{*}$ \\
\hline O9 & $-0.1599(8)$ & $0.30041(10)$ & $-0.1734(5)$ & $0.0271(8)$ \\
\hline H16 & -0.315580 & 0.306148 & -0.235115 & $0.041 *$ \\
\hline $\mathrm{O} 7$ & $0.2127(8)$ & $0.32976(9)$ & $0.3684(5)$ & $0.0246(8)$ \\
\hline $\mathrm{O} 14$ & $0.9488(8)$ & $0.62845(9)$ & $0.0366(5)$ & $0.0243(8)$ \\
\hline
\end{tabular}




\begin{tabular}{|c|c|c|c|c|}
\hline $\mathrm{H} 28$ & 0.880367 & 0.614191 & 0.091229 & $0.036^{*}$ \\
\hline $\mathrm{O} 10$ & $0.2774(9)$ & $0.27554(10)$ & $0.1138(6)$ & $0.0330(9)$ \\
\hline H18 & 0.314497 & 0.255156 & 0.139478 & $0.050 *$ \\
\hline $\mathrm{C} 20$ & $0.9358(10)$ & $0.58351(13)$ & $0.6136(7)$ & $0.0181(10)$ \\
\hline H35 & 0.750213 & 0.590714 & 0.618473 & $0.022^{*}$ \\
\hline $\mathrm{C} 8$ & $0.0534(11)$ & 0.34525 (13) & $0.0480(8)$ & $0.0205(11)$ \\
\hline H13 & 0.239621 & 0.340667 & 0.035068 & $0.025^{*}$ \\
\hline $\mathrm{C} 24$ & $0.5550(11)$ & $0.54250(13)$ & $0.0855(7)$ & $0.0198(11)$ \\
\hline $\mathrm{H} 42$ & 0.546449 & 0.517815 & 0.061304 & $0.024^{*}$ \\
\hline H43 & 0.377551 & 0.549730 & 0.101453 & $0.024 *$ \\
\hline $\mathrm{C} 1$ & $0.4517(10)$ & $0.46096(14)$ & $0.6919(7)$ & $0.0213(11)$ \\
\hline H1 & 0.426733 & 0.479139 & 0.775768 & $0.026^{*}$ \\
\hline $\mathrm{C} 23$ & $0.7860(10)$ & $0.55020(12)$ & $0.2579(7)$ & $0.0173(10)$ \\
\hline H41 & 0.965279 & 0.544004 & 0.238128 & $0.021^{*}$ \\
\hline $\mathrm{C} 21$ & $0.9528(10)$ & $0.54400(12)$ & $0.6007(7)$ & $0.0173(10)$ \\
\hline H37 & 1.140872 & 0.538424 & 0.594368 & $0.021^{*}$ \\
\hline C19 & $0.9984(10)$ & $0.59750(12)$ & $0.4411(7)$ & $0.0170(10)$ \\
\hline H34 & 1.176610 & 0.588406 & 0.431537 & $0.020^{*}$ \\
\hline C6 & $0.1254(11)$ & $0.45800(13)$ & $0.1900(8)$ & $0.0226(11)$ \\
\hline H9 & 0.198228 & 0.480200 & 0.165561 & $0.027^{*}$ \\
\hline H10 & 0.138072 & 0.442088 & 0.093988 & $0.027^{*}$ \\
\hline C14 & $1.2288(11)$ & $0.67893(13)$ & $0.0680(7)$ & 0.0209 (11) \\
\hline $\mathrm{H} 25$ & 1.387599 & 0.664168 & 0.066897 & $0.025^{*}$ \\
\hline $\mathrm{C} 17$ & $1.3112(10)$ & $0.68082(13)$ & $0.4579(7)$ & $0.0195(10)$ \\
\hline H30 & 1.159935 & 0.696013 & 0.468979 & $0.023 *$ \\
\hline $\mathrm{C} 7$ & $0.0784(11)$ & 0.35677 (13) & $0.2441(7)$ & $0.0196(10)$ \\
\hline H12 & -0.106122 & 0.361692 & 0.259024 & $0.024^{*}$ \\
\hline $\mathrm{C} 5$ & $0.3006(11)$ & 0.44434 (13) & $0.3749(7)$ & 0.0219 (11) \\
\hline H8 & 0.494524 & 0.442104 & 0.372289 & $0.026^{*}$ \\
\hline $\mathrm{C} 3$ & $0.3540(11)$ & $0.39801(13)$ & $0.6144(7)$ & 0.0218 \\
\hline H5 & 0.546689 & 0.392342 & 0.619038 & $0.026^{*}$ \\
\hline $\mathrm{C} 13$ & $1.3417(11)$ & $0.71003(13)$ & $0.1898(7)$ & 0.0215 \\
\hline $\mathrm{H} 23$ & 1.190363 & 0.725882 & 0.193211 & $0.026^{*}$ \\
\hline $\mathrm{C} 15$ & $1.0364(11)$ & $0.65786(13)$ & $0.1498(7)$ & $0.0202(10)$ \\
\hline $\mathrm{H} 27$ & 0.872987 & 0.671902 & 0.148950 & $0.024^{*}$ \\
\hline $\mathrm{C} 22$ & $0.7497(10)$ & $0.53044(13)$ & $0.4241(7)$ & $0.0170(10)$ \\
\hline H39 & 0.786548 & 0.505824 & 0.410362 & $0.020^{*}$ \\
\hline $\mathrm{C} 2$ & $0.3514(11)$ & $0.42673(13)$ & $0.7521(7)$ & $0.0187(10)$ \\
\hline H3 & 0.158699 & 0.429934 & 0.755627 & $0.022^{*}$ \\
\hline $\mathrm{C} 4$ & $0.1963(11)$ & $0.40929(13)$ & $0.4195(7)$ & $0.0195(11)$ \\
\hline H7 & -0.003568 & 0.410561 & 0.407681 & $0.023^{*}$ \\
\hline $\mathrm{C} 18$ & $1.4912(11)$ & $0.67173(14)$ & $0.6449(7)$ & $0.0234(11)$ \\
\hline H31 & 1.395514 & 0.654941 & 0.700426 & $0.028^{*}$ \\
\hline H32 & 1.661968 & 0.661189 & 0.634382 & $0.028^{*}$ \\
\hline $\mathrm{C} 16$ & $1.1883(11)$ & $0.64855(13)$ & $0.3472(7)$ & $0.0208(11)$ \\
\hline $\mathrm{H} 29$ & 1.338142 & 0.632143 & 0.348393 & $0.025^{*}$ \\
\hline C9 & $-0.1179(12)$ & $0.31185(14)$ & $0.0111(8)$ & $0.0249(11)$ \\
\hline H15 & -0.300892 & 0.316837 & 0.028450 & $0.030^{*}$ \\
\hline
\end{tabular}




\begin{tabular}{lllll}
$\mathrm{C} 10$ & $0.0178(12)$ & $0.28397(13)$ & $0.1469(8)$ & $0.0268(12)$ \\
$\mathrm{H} 17$ & -0.101628 & 0.263421 & 0.128141 & $0.032^{*}$ \\
$\mathrm{C} 11$ & $0.0587(13)$ & $0.29805(13)$ & $0.3428(8)$ & $0.0286(12)$ \\
$\mathrm{H} 19$ & -0.123605 & 0.302114 & 0.363263 & $0.034^{*}$ \\
$\mathrm{C} 12$ & $0.2247(14)$ & $0.27321(15)$ & $0.4875(8)$ & $0.0317(13)$ \\
$\mathrm{H} 20$ & 0.121673 & 0.251740 & 0.480278 & $0.038^{*}$ \\
$\mathrm{H} 21$ & 0.399212 & 0.267975 & 0.461291 & $0.038^{*}$ \\
\hline
\end{tabular}

Atomic displacement parameters $\left(\AA^{2}\right)$

\begin{tabular}{|c|c|c|c|c|c|c|}
\hline & $U^{11}$ & $U^{22}$ & $U^{\beta 3}$ & $U^{12}$ & $U^{13}$ & $U^{23}$ \\
\hline $\mathrm{O} 15$ & $0.0173(17)$ & $0.0172(16)$ & $0.0209(18)$ & $-0.0002(13)$ & $0.0082(13)$ & $0.0022(14)$ \\
\hline O5 & $0.0161(17)$ & $0.0164(16)$ & $0.024(2)$ & $0.0003(13)$ & $0.0020(14)$ & $-0.0004(14)$ \\
\hline $\mathrm{O} 18$ & $0.0148(17)$ & $0.0183(17)$ & $0.0165(17)$ & $-0.0005(13)$ & $0.0025(13)$ & -0.0011 \\
\hline O19 & $0.0222(19)$ & $0.0210(17)$ & $0.0166(18)$ & $-0.0009(14)$ & $0.0025(14)$ & $-0.0026(14)$ \\
\hline $\mathrm{O} 4$ & $0.0201(18)$ & $0.0174(16)$ & $0.0233(19)$ & $-0.0019(14)$ & 0.0077 (14) & $-0.0017(15)$ \\
\hline $\mathrm{O} 21$ & $0.0125(17)$ & $0.0173(17)$ & $0.027(2)$ & $-0.0005(13)$ & $0.0073(14)$ & $0.0017(15)$ \\
\hline $\mathrm{O} 2$ & $0.023(2)$ & $0.0237(19)$ & $0.0196(19)$ & 0.0007 (14) & $0.0043(15)$ & $0.0013(15)$ \\
\hline $\mathrm{O} 22$ & $0.0196(17)$ & $0.029(2)$ & $0.0198(19)$ & $0.0023(15)$ & $0.0045(14)$ & $0.0028(15)$ \\
\hline $\mathrm{O} 8$ & $0.029(2)$ & $0.0233(18)$ & 0.0177 (19) & $0.0052(15)$ & $0.0074(15)$ & $0.0051(16)$ \\
\hline O6 & $0.0172(18)$ & $0.029(2)$ & $0.026(2)$ & $0.0030(15)$ & $0.0012(14)$ & $-0.0057(16)$ \\
\hline $\mathrm{O} 1$ & $0.0186(18)$ & $0.0229(18)$ & $0.032(2)$ & $-0.0011(14)$ & 0.0059 (15) & $0.0012(17)$ \\
\hline O17 & $0.026(2)$ & $0.0273(19)$ & $0.023(2)$ & $-0.0052(15)$ & $0.0090(15)$ & $-0.0036(16)$ \\
\hline O16 & $0.0262(19)$ & $0.0230(19)$ & $0.0212(19)$ & $-0.0078(15)$ & $0.0049(15)$ & $0.0014(15)$ \\
\hline $\mathrm{O} 20$ & $0.0215(19)$ & $0.0214(17)$ & 0.0195 (19) & $0.0002(14)$ & $0.0058(14)$ & $0.0007(15)$ \\
\hline $\mathrm{O} 13$ & $0.0216(19)$ & $0.032(2)$ & $0.0235(19)$ & $-0.0018(16)$ & $0.0056(15)$ & $0.0026(16)$ \\
\hline $\mathrm{O} 12$ & $0.035(2)$ & $0.025(2)$ & $0.031(2)$ & $-0.0097(17)$ & $0.0120(18)$ & $-0.0032(17)$ \\
\hline $\mathrm{O} 3$ & $0.040(2)$ & $0.0153(16)$ & $0.024(2)$ & $-0.0033(16)$ & $0.0128(17)$ & $-0.0002(15)$ \\
\hline O11 & $0.044(3)$ & $0.026(2)$ & $0.025(2)$ & $0.0022(17)$ & $0.0102(18)$ & $0.0042(17)$ \\
\hline O9 & $0.029(2)$ & $0.028(2)$ & $0.0200(19)$ & $-0.0021(16)$ & $0.0000(15)$ & $-0.0044(16)$ \\
\hline $\mathrm{O} 7$ & $0.034(2)$ & $0.0160(17)$ & $0.021(2)$ & $-0.0001(15)$ & $0.0030(15)$ & $0.0012(15)$ \\
\hline O14 & $0.030(2)$ & $0.0206(18)$ & $0.023(2)$ & $-0.0083(15)$ & $0.0076(15)$ & $-0.0009(15)$ \\
\hline $\mathrm{O} 10$ & $0.043(2)$ & $0.0229(18)$ & $0.034(2)$ & $0.0112(17)$ & $0.0104(18)$ & $0.0000(17)$ \\
\hline $\mathrm{C} 20$ & $0.014(2)$ & $0.022(2)$ & $0.016(2)$ & $-0.0002(19)$ & 0.0009 (18) & $-0.002(2)$ \\
\hline $\mathrm{C} 8$ & $0.020(3)$ & $0.018(2)$ & $0.023(3)$ & $-0.0012(19)$ & $0.005(2)$ & $0.001(2)$ \\
\hline $\mathrm{C} 24$ & $0.018(3)$ & $0.019(2)$ & $0.021(3)$ & $0.0002(18)$ & $0.002(2)$ & $0.001(2)$ \\
\hline $\mathrm{C} 1$ & $0.013(2)$ & $0.024(3)$ & $0.024(3)$ & $-0.001(2)$ & $0.000(2)$ & $0.001(2)$ \\
\hline $\mathrm{C} 23$ & $0.015(2)$ & $0.019(2)$ & $0.018(2)$ & $0.0020(19)$ & $0.0045(18)$ & $-0.005(2)$ \\
\hline $\mathrm{C} 21$ & $0.014(2)$ & $0.021(3)$ & $0.017(2)$ & $0.0005(18)$ & $0.0042(18)$ & $0.001(2)$ \\
\hline C19 & $0.017(3)$ & $0.017(2)$ & $0.017(2)$ & $0.0024(18)$ & 0.0035 (19) & $-0.0022(19)$ \\
\hline C6 & 0.023 & $0.020(2)$ & $0.027(3)$ & $0.001(2)$ & $0.010(2)$ & $0.000(2)$ \\
\hline $\mathrm{C} 14$ & $0.024(3)$ & $0.018(2)$ & $0.021(3)$ & $0.000(2)$ & $0.007(2)$ & $0.002(2)$ \\
\hline $\mathrm{C} 17$ & 0.019 (3) & $0.022(3)$ & $0.020(3)$ & $-0.0018(19)$ & 0.0090 (19) & $0.001(2)$ \\
\hline $\mathrm{C} 7$ & $0.023(3)$ & $0.016(2)$ & $0.020(3)$ & $-0.002(2)$ & $0.007(2)$ & $0.001(2)$ \\
\hline $\mathrm{C} 5$ & $0.017(3)$ & $0.019(2)$ & $0.029(3)$ & $0.001(2)$ & $0.004(2)$ & $0.002(2)$ \\
\hline $\mathrm{C} 3$ & $0.026(3)$ & $0.019(2)$ & $0.022(3)$ & $0.003(2)$ & $0.007(2)$ & $0.001(2)$ \\
\hline $\mathrm{C} 13$ & $0.027(3)$ & $0.018(2)$ & $0.020(3)$ & $-0.001(2)$ & $0.007(2)$ & $0.004(2)$ \\
\hline $\mathrm{C} 15$ & $0.022(3)$ & $0.020(2)$ & 0.018 (3) & $0.001(2)$ & $0.006(2)$ & $-0.002(2)$ \\
\hline
\end{tabular}




\begin{tabular}{lllllll} 
C22 & $0.011(2)$ & $0.018(2)$ & $0.024(3)$ & $0.0000(18)$ & $0.0084(19)$ & $0.000(2)$ \\
C2 & $0.016(3)$ & $0.020(2)$ & $0.020(3)$ & $0.0027(19)$ & $0.0052(19)$ & $0.002(2)$ \\
C4 & $0.022(3)$ & $0.016(2)$ & $0.018(3)$ & $-0.0006(19)$ & $0.0025(19)$ & $-0.003(2)$ \\
C18 & $0.025(3)$ & $0.021(2)$ & $0.025(3)$ & $-0.003(2)$ & $0.008(2)$ & $0.003(2)$ \\
C16 & $0.019(3)$ & $0.019(2)$ & $0.027(3)$ & $-0.001(2)$ & $0.011(2)$ & $0.001(2)$ \\
C9 & $0.029(3)$ & $0.020(2)$ & $0.025(3)$ & $-0.001(2)$ & $0.007(2)$ & $-0.003(2)$ \\
C10 & $0.038(3)$ & $0.017(3)$ & $0.024(3)$ & $-0.002(2)$ & $0.007(2)$ & $-0.002(2)$ \\
C11 & $0.043(3)$ & $0.018(3)$ & $0.024(3)$ & $-0.003(2)$ & $0.009(2)$ & $0.002(2)$ \\
C12 & $0.049(4)$ & $0.023(3)$ & $0.021(3)$ & $0.003(3)$ & $0.007(2)$ & $0.001(2)$ \\
\hline
\end{tabular}

Geometric parameters $\left(\AA,{ }^{\circ}\right)$

\begin{tabular}{|c|c|c|c|}
\hline $\mathrm{O} 15-\mathrm{C} 19$ & $1.390(6)$ & $\mathrm{C} 20-\mathrm{C} 19$ & $1.529(7)$ \\
\hline $\mathrm{O} 15-\mathrm{C} 16$ & $1.443(6)$ & C $8-\mathrm{H} 13$ & 0.9800 \\
\hline $\mathrm{O} 5-\mathrm{C} 1$ & $1.428(6)$ & $\mathrm{C} 8-\mathrm{C} 7$ & $1.527(8)$ \\
\hline $\mathrm{O} 5-\mathrm{C} 5$ & $1.440(6)$ & $\mathrm{C} 8-\mathrm{C} 9$ & $1.531(7)$ \\
\hline $\mathrm{O} 18-\mathrm{C} 23$ & $1.437(6)$ & $\mathrm{C} 24-\mathrm{H} 42$ & 0.9700 \\
\hline $\mathrm{O} 18-\mathrm{C} 19$ & $1.433(6)$ & $\mathrm{C} 24-\mathrm{H} 43$ & 0.9700 \\
\hline $\mathrm{O} 19-\mathrm{H} 36$ & 0.8200 & $\mathrm{C} 24-\mathrm{C} 23$ & $1.515(7)$ \\
\hline $\mathrm{O} 19-\mathrm{C} 20$ & $1.429(6)$ & $\mathrm{C} 1-\mathrm{H} 1$ & 0.9800 \\
\hline $\mathrm{O} 4-\mathrm{C} 7$ & $1.383(6)$ & $\mathrm{C} 1-\mathrm{C} 2$ & $1.529(7)$ \\
\hline $\mathrm{O} 4-\mathrm{C} 4$ & $1.437(6)$ & $\mathrm{C} 23-\mathrm{H} 41$ & 0.9800 \\
\hline $\mathrm{O} 21-\mathrm{H} 40$ & 0.8200 & $\mathrm{C} 23-\mathrm{C} 22$ & $1.530(7)$ \\
\hline $\mathrm{O} 21-\mathrm{C} 22$ & $1.424(6)$ & $\mathrm{C} 21-\mathrm{H} 37$ & 0.9800 \\
\hline $\mathrm{O} 2-\mathrm{H} 4$ & 0.8200 & $\mathrm{C} 21-\mathrm{C} 22$ & $1.532(7)$ \\
\hline $\mathrm{O} 2-\mathrm{C} 2$ & $1.420(7)$ & C19-H34 & 0.9800 \\
\hline $\mathrm{O} 22-\mathrm{H} 44$ & 0.8200 & C6- $-\mathrm{H} 9$ & 0.9700 \\
\hline $\mathrm{O} 22-\mathrm{C} 24$ & $1.432(6)$ & C6-H10 & 0.9700 \\
\hline O8-H14 & 0.8200 & $\mathrm{C} 6-\mathrm{C} 5$ & $1.528(8)$ \\
\hline $\mathrm{O} 8-\mathrm{C} 8$ & $1.410(6)$ & $\mathrm{C} 14-\mathrm{H} 25$ & 0.9800 \\
\hline O6-H11 & 0.8200 & $\mathrm{C} 14-\mathrm{C} 13$ & $1.526(7)$ \\
\hline $\mathrm{O} 6-\mathrm{C} 6$ & $1.426(6)$ & $\mathrm{C} 14-\mathrm{C} 15$ & $1.520(7)$ \\
\hline $\mathrm{O} 1-\mathrm{H} 2$ & 0.8200 & C17- $\mathrm{H} 30$ & 0.9800 \\
\hline $\mathrm{O} 1-\mathrm{C} 1$ & $1.390(6)$ & $\mathrm{C} 17-\mathrm{C} 18$ & $1.497(7)$ \\
\hline $\mathrm{O} 17-\mathrm{H} 33$ & 0.8200 & $\mathrm{C} 17-\mathrm{C} 16$ & $1.533(7)$ \\
\hline $\mathrm{O} 17-\mathrm{C} 18$ & $1.430(7)$ & C7-H12 & 0.9800 \\
\hline $\mathrm{O} 16-\mathrm{C} 17$ & $1.423(6)$ & $\mathrm{C} 5-\mathrm{H} 8$ & 0.9800 \\
\hline $\mathrm{O} 16-\mathrm{C} 13$ & $1.414(7)$ & $\mathrm{C} 5-\mathrm{C} 4$ & $1.523(7)$ \\
\hline $\mathrm{O} 20-\mathrm{H} 38$ & 0.8200 & $\mathrm{C} 3-\mathrm{H} 5$ & 0.9800 \\
\hline $\mathrm{O} 20-\mathrm{C} 21$ & $1.425(6)$ & $\mathrm{C} 3-\mathrm{C} 2$ & $1.528(7)$ \\
\hline $\mathrm{O} 13-\mathrm{H} 26$ & 0.8200 & $\mathrm{C} 3-\mathrm{C} 4$ & $1.535(7)$ \\
\hline $\mathrm{O} 13-\mathrm{C} 14$ & $1.411(7)$ & $\mathrm{C} 13-\mathrm{H} 23$ & 0.9800 \\
\hline $\mathrm{O} 12-\mathrm{H} 24$ & 0.8200 & $\mathrm{C} 15-\mathrm{H} 27$ & 0.9800 \\
\hline $\mathrm{O} 12-\mathrm{C} 13$ & $1.399(7)$ & $\mathrm{C} 15-\mathrm{C} 16$ & $1.524(8)$ \\
\hline $\mathrm{O} 3-\mathrm{H} 6$ & 0.8200 & $\mathrm{C} 22-\mathrm{H} 39$ & 0.9800 \\
\hline $\mathrm{O} 3-\mathrm{C} 3$ & $1.429(7)$ & $\mathrm{C} 2-\mathrm{H} 3$ & 0.9800 \\
\hline $\mathrm{O} 11-\mathrm{H} 22$ & 0.8200 & $\mathrm{C} 4-\mathrm{H} 7$ & 0.9800 \\
\hline $\mathrm{O} 11-\mathrm{C} 12$ & $1.415(7)$ & $\mathrm{C} 18-\mathrm{H} 31$ & 0.9700 \\
\hline
\end{tabular}




\begin{tabular}{|c|c|c|c|}
\hline O9- $\mathrm{H} 16$ & 0.8200 & $\mathrm{C} 18-\mathrm{H} 32$ & 0.9700 \\
\hline $\mathrm{O} 9-\mathrm{C} 9$ & $1.429(7)$ & $\mathrm{C} 16-\mathrm{H} 29$ & 0.9800 \\
\hline $\mathrm{O} 7-\mathrm{C} 7$ & $1.442(6)$ & C9-H15 & 0.9800 \\
\hline $\mathrm{O} 7-\mathrm{C} 11$ & $1.432(7)$ & $\mathrm{C} 9-\mathrm{C} 10$ & $1.515(8)$ \\
\hline $\mathrm{O} 14-\mathrm{H} 28$ & 0.8200 & $\mathrm{C} 10-\mathrm{H} 17$ & 0.9800 \\
\hline $\mathrm{O} 14-\mathrm{C} 15$ & $1.419(6)$ & $\mathrm{C} 10-\mathrm{C} 11$ & $1.544(8)$ \\
\hline $\mathrm{O} 10-\mathrm{H} 18$ & 0.8200 & $\mathrm{C} 11-\mathrm{H} 19$ & 0.9800 \\
\hline $\mathrm{O} 10-\mathrm{C} 10$ & $1.428(7)$ & $\mathrm{C} 11-\mathrm{C} 12$ & $1.520(8)$ \\
\hline $\mathrm{C} 20-\mathrm{H} 35$ & 0.9800 & $\mathrm{C} 12-\mathrm{H} 20$ & 0.9700 \\
\hline $\mathrm{C} 20-\mathrm{C} 21$ & $1.534(7)$ & $\mathrm{C} 12-\mathrm{H} 21$ & 0.9700 \\
\hline $\mathrm{C} 19-\mathrm{O} 15-\mathrm{C} 16$ & $114.6(4)$ & $\mathrm{O} 4-\mathrm{C} 7-\mathrm{C} 8$ & $109.7(4)$ \\
\hline $\mathrm{C} 1-\mathrm{O} 5-\mathrm{C} 5$ & $113.8(4)$ & $\mathrm{O} 4-\mathrm{C} 7-\mathrm{H} 12$ & 110.3 \\
\hline $\mathrm{C} 19-\mathrm{O} 18-\mathrm{C} 23$ & $110.8(3)$ & $\mathrm{O} 7-\mathrm{C} 7-\mathrm{C} 8$ & $108.9(4)$ \\
\hline $\mathrm{C} 20-\mathrm{O} 19-\mathrm{H} 36$ & 109.5 & $\mathrm{O} 7-\mathrm{C} 7-\mathrm{H} 12$ & 110.3 \\
\hline $\mathrm{C} 7-\mathrm{O} 4-\mathrm{C} 4$ & $117.3(4)$ & $\mathrm{C} 8-\mathrm{C} 7-\mathrm{H} 12$ & 110.3 \\
\hline $\mathrm{C} 22-\mathrm{O} 21-\mathrm{H} 40$ & 109.5 & $\mathrm{O} 5-\mathrm{C} 5-\mathrm{C} 6$ & $107.4(4)$ \\
\hline $\mathrm{C} 2-\mathrm{O} 2-\mathrm{H} 4$ & 109.5 & $\mathrm{O} 5-\mathrm{C} 5-\mathrm{H} 8$ & 109.2 \\
\hline $\mathrm{C} 24-\mathrm{O} 22-\mathrm{H} 44$ & 109.5 & $\mathrm{O} 5-\mathrm{C} 5-\mathrm{C} 4$ & $110.2(4)$ \\
\hline $\mathrm{C} 8-\mathrm{O} 8-\mathrm{H} 14$ & 109.5 & $\mathrm{C} 6-\mathrm{C} 5-\mathrm{H} 8$ & 109.2 \\
\hline $\mathrm{C} 6-\mathrm{O} 6-\mathrm{H} 11$ & 109.5 & $\mathrm{C} 4-\mathrm{C} 5-\mathrm{C} 6$ & $111.6(4)$ \\
\hline $\mathrm{C} 1-\mathrm{O} 1-\mathrm{H} 2$ & 109.5 & $\mathrm{C} 4-\mathrm{C} 5-\mathrm{H} 8$ & 109.2 \\
\hline $\mathrm{C} 18-\mathrm{O} 17-\mathrm{H} 33$ & 109.5 & $\mathrm{O} 3-\mathrm{C} 3-\mathrm{H} 5$ & 109.5 \\
\hline $\mathrm{C} 13-\mathrm{O} 16-\mathrm{C} 17$ & $113.4(4)$ & $\mathrm{O} 3-\mathrm{C} 3-\mathrm{C} 2$ & $105.8(4)$ \\
\hline $\mathrm{C} 21-\mathrm{O} 20-\mathrm{H} 38$ & 109.5 & $\mathrm{O} 3-\mathrm{C} 3-\mathrm{C} 4$ & $111.7(4)$ \\
\hline $\mathrm{C} 14-\mathrm{O} 13-\mathrm{H} 26$ & 109.5 & $\mathrm{C} 2-\mathrm{C} 3-\mathrm{H} 5$ & 109.5 \\
\hline $\mathrm{C} 13-\mathrm{O} 12-\mathrm{H} 24$ & 109.5 & $\mathrm{C} 2-\mathrm{C} 3-\mathrm{C} 4$ & $110.8(4)$ \\
\hline $\mathrm{C} 3-\mathrm{O} 3-\mathrm{H} 6$ & 109.5 & $\mathrm{C} 4-\mathrm{C} 3-\mathrm{H} 5$ & 109.5 \\
\hline $\mathrm{C} 12-\mathrm{O} 11-\mathrm{H} 22$ & 109.5 & $\mathrm{O} 16-\mathrm{C} 13-\mathrm{C} 14$ & $110.3(4)$ \\
\hline $\mathrm{C} 9-\mathrm{O} 9-\mathrm{H} 16$ & 109.5 & $\mathrm{O} 16-\mathrm{C} 13-\mathrm{H} 23$ & 110.5 \\
\hline $\mathrm{C} 11-\mathrm{O} 7-\mathrm{C} 7$ & $113.3(4)$ & $\mathrm{O} 12-\mathrm{C} 13-\mathrm{O} 16$ & $107.8(4)$ \\
\hline $\mathrm{C} 15-\mathrm{O} 14-\mathrm{H} 28$ & 109.5 & $\mathrm{O} 12-\mathrm{C} 13-\mathrm{C} 14$ & $107.3(4)$ \\
\hline $\mathrm{C} 10-\mathrm{O} 10-\mathrm{H} 18$ & 109.5 & $\mathrm{O} 12-\mathrm{C} 13-\mathrm{H} 23$ & 110.5 \\
\hline $\mathrm{O} 19-\mathrm{C} 20-\mathrm{H} 35$ & 110.8 & $\mathrm{C} 14-\mathrm{C} 13-\mathrm{H} 23$ & 110.5 \\
\hline $\mathrm{O} 19-\mathrm{C} 20-\mathrm{C} 21$ & $110.0(4)$ & $\mathrm{O} 14-\mathrm{C} 15-\mathrm{C} 14$ & $107.7(4)$ \\
\hline $\mathrm{O} 19-\mathrm{C} 20-\mathrm{C} 19$ & $108.7(4)$ & $\mathrm{O} 14-\mathrm{C} 15-\mathrm{H} 27$ & 108.9 \\
\hline $\mathrm{C} 21-\mathrm{C} 20-\mathrm{H} 35$ & 110.8 & $\mathrm{O} 14-\mathrm{C} 15-\mathrm{C} 16$ & $113.1(4)$ \\
\hline $\mathrm{C} 19-\mathrm{C} 20-\mathrm{H} 35$ & 110.8 & $\mathrm{C} 14-\mathrm{C} 15-\mathrm{H} 27$ & 108.9 \\
\hline $\mathrm{C} 19-\mathrm{C} 20-\mathrm{C} 21$ & $105.6(4)$ & $\mathrm{C} 14-\mathrm{C} 15-\mathrm{C} 16$ & $109.3(4)$ \\
\hline $\mathrm{O} 8-\mathrm{C} 8-\mathrm{H} 13$ & 109.2 & $\mathrm{C} 16-\mathrm{C} 15-\mathrm{H} 27$ & 108.9 \\
\hline $\mathrm{O} 8-\mathrm{C} 8-\mathrm{C} 7$ & $109.8(4)$ & $\mathrm{O} 21-\mathrm{C} 22-\mathrm{C} 23$ & $109.3(4)$ \\
\hline $\mathrm{O} 8-\mathrm{C} 8-\mathrm{C} 9$ & $111.1(4)$ & $\mathrm{O} 21-\mathrm{C} 22-\mathrm{C} 21$ & $109.8(4)$ \\
\hline $\mathrm{C} 7-\mathrm{C} 8-\mathrm{H} 13$ & 109.2 & $\mathrm{O} 21-\mathrm{C} 22-\mathrm{H} 39$ & 109.1 \\
\hline $\mathrm{C} 7-\mathrm{C} 8-\mathrm{C} 9$ & $108.3(4)$ & $\mathrm{C} 23-\mathrm{C} 22-\mathrm{C} 21$ & $110.5(4)$ \\
\hline $\mathrm{C} 9-\mathrm{C} 8-\mathrm{H} 13$ & 109.2 & $\mathrm{C} 23-\mathrm{C} 22-\mathrm{H} 39$ & 109.1 \\
\hline $\mathrm{O} 22-\mathrm{C} 24-\mathrm{H} 42$ & 109.8 & $\mathrm{C} 21-\mathrm{C} 22-\mathrm{H} 39$ & 109.1 \\
\hline $\mathrm{O} 22-\mathrm{C} 24-\mathrm{H} 43$ & 109.8 & $\mathrm{O} 2-\mathrm{C} 2-\mathrm{C} 1$ & $110.7(4)$ \\
\hline $\mathrm{O} 22-\mathrm{C} 24-\mathrm{C} 23$ & $109.2(4)$ & $\mathrm{O} 2-\mathrm{C} 2-\mathrm{C} 3$ & $111.5(4)$ \\
\hline
\end{tabular}




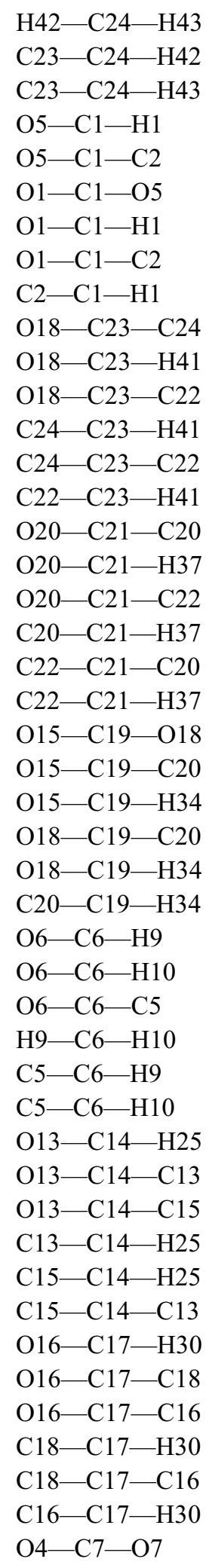

108.3

109.8

109.8

108.2

109.3 (4)

112.8 (4)

108.2

109.9 (4)

108.2

105.9 (4)

109.3

$110.8(4)$

109.3

$112.2(4)$

109.3

$113.6(4)$

107.0

$110.6(4)$

107.0

$111.2(4)$

107.0

106.9 (4)

$111.2(4)$

110.2

108.1 (4)

110.2

110.2

109.4

109.4

$111.2(4)$

108.0

109.4

109.4

107.4

$110.1(4)$

$114.1(4)$

107.4

107.4

$110.1(4)$

109.5

106.4 (4)

$110.0(4)$

109.5

$111.9(4)$

109.5

107.4 (4)
$\mathrm{O} 2-\mathrm{C} 2-\mathrm{H} 3$

$\mathrm{C} 1-\mathrm{C} 2-\mathrm{H} 3$

$\mathrm{C} 3-\mathrm{C} 2-\mathrm{C} 1$

$\mathrm{C} 3-\mathrm{C} 2-\mathrm{H} 3$

$\mathrm{O} 4-\mathrm{C} 4-\mathrm{C} 5$

$\mathrm{O} 4-\mathrm{C} 4-\mathrm{C} 3$

$\mathrm{O} 4-\mathrm{C} 4-\mathrm{H} 7$

$\mathrm{C} 5-\mathrm{C} 4-\mathrm{C} 3$

$\mathrm{C} 5-\mathrm{C} 4-\mathrm{H} 7$

$\mathrm{C} 3-\mathrm{C} 4-\mathrm{H} 7$

$\mathrm{O} 17-\mathrm{C} 18-\mathrm{C} 17$

$\mathrm{O} 17-\mathrm{C} 18-\mathrm{H} 31$

$\mathrm{O} 17-\mathrm{C} 18-\mathrm{H} 32$

$\mathrm{C} 17-\mathrm{C} 18-\mathrm{H} 31$

C17-C18-H32

$\mathrm{H} 31-\mathrm{C} 18-\mathrm{H} 32$

$\mathrm{O} 15-\mathrm{C} 16-\mathrm{C} 17$

$\mathrm{O} 15-\mathrm{C} 16-\mathrm{C} 15$

$\mathrm{O} 15-\mathrm{C} 16-\mathrm{H} 29$

$\mathrm{C} 17-\mathrm{C} 16-\mathrm{H} 29$

$\mathrm{C} 15-\mathrm{C} 16-\mathrm{C} 17$

$\mathrm{C} 15-\mathrm{C} 16-\mathrm{H} 29$

O9- $\mathrm{C} 9-\mathrm{C} 8$

O9- $\mathrm{C} 9-\mathrm{H} 15$

$\mathrm{O} 9-\mathrm{C} 9-\mathrm{C} 10$

C8-C9-H15

$\mathrm{C} 10-\mathrm{C} 9-\mathrm{C} 8$

$\mathrm{C} 10-\mathrm{C} 9-\mathrm{H} 15$

$\mathrm{O} 10-\mathrm{C} 10-\mathrm{C} 9$

$\mathrm{O} 10-\mathrm{C} 10-\mathrm{H} 17$

$\mathrm{O} 10-\mathrm{C} 10-\mathrm{C} 11$

C9- $\mathrm{C} 10-\mathrm{H} 17$

C9- $\mathrm{C} 10-\mathrm{C} 11$

$\mathrm{C} 11-\mathrm{C} 10-\mathrm{H} 17$

O7-C11-C10

O7-C11-H19

$\mathrm{O} 7-\mathrm{C} 11-\mathrm{C} 12$

C10-C11-H19

C12-C11-C10

C12-C11-H19

$\mathrm{O} 11-\mathrm{C} 12-\mathrm{C} 11$

$\mathrm{O} 11-\mathrm{C} 12-\mathrm{H} 20$

$\mathrm{O} 11-\mathrm{C} 12-\mathrm{H} 21$

$\mathrm{C} 11-\mathrm{C} 12-\mathrm{H} 20$

$\mathrm{C} 11-\mathrm{C} 12-\mathrm{H} 21$

$\mathrm{H} 20-\mathrm{C} 12-\mathrm{H} 21$
107.9

107.9

110.9 (4)

107.9

105.4 (4)

111.3 (4)

109.8

$110.6(4)$

109.8

109.8

$111.6(4)$

109.3

109.3

109.3

109.3

108.0

105.9 (4)

111.4 (4)

109.4

109.4

$111.2(4)$

109.4

111.2 (4)

107.8

111.3 (4)

107.8

110.6 (4)

107.8

107.4 (4)

109.7

$111.6(5)$

109.7

108.7 (4)

109.7

110.7 (4)

109.3

106.1 (5)

109.3

112.0 (4)

109.3

113.3 (5)

108.9

108.9

108.9

108.9

107.7 